\title{
SEBARAN SPASIAL BIOMASSA IKAN PELAGIS DI PERAIRAN SELAT LOMBOK
}

\author{
Badrudin", I Nyoman Radiarta"' dan Edi Mulyadi Amin"
}

\begin{abstract}
ABSTRAK
Tersedianya data dan informasi tentang potensi sumber daya ikan pelagis di perairan Selat Lombok merupakan salah satu dasar bagi pengembangan dan pemanfaatannya. Survai sumber daya ikan pelagis dengan metocle akustik telah dilakukan pada bulan Desember 1997. dengan tujuan untuk menduga kelimpahan biomassanya. Selama survai ini dari 68 titik penarikan contoh telah diperoleh data kisaran kepadatan biomassa ikan pelagis antara 0.001 $-29,225$ ton $/ \mathrm{km}^{2}$. Rata-rata kepadatan biomassa ikan pelagis pada kedalaman $<50 \mathrm{~m}$ adalah sekitar $1,35 \mathrm{ton} / \mathrm{km}^{2}$ dan antara $50.100 \mathrm{~m}$ adalah sekitar $4,43 \mathrm{ton} / \mathrm{km}^{2}$. Uji statistik terhadap rata-rata kepadatan biomassa tersebut menunjukkan perbedaan yang nyata pada selang kepercayaan 95\%. Kepadatan biomassa ikan pelagis pada pagi hari dan sore hari tidak menujukkan perbedaan yang nyata. Hasil perhitungan Green Index menujukkan bahwa perilaku pengelompokan ikan cenderung terjadi pada sore hari. Dugaan biomassa total ikan pelagis selama periode penelitian di perairan Selat Lombok adalah sekitar 21.000 ton.
\end{abstract}

\section{ABSTRACT: Spatial distribution of pelagic fish biomass in the waters of Lombok Strait. By: Badiudin. I Nyoman Radiarta, and Edi Mulyadi Amin.}

The availability of clata and information of fishery resource in a certain area provides one of the basic consideration for optimum exploitation and dovelopment. A survey of aroustic abundanc" estimation of pelagic fish biomass in Lombol Strait was carried out in December 1997. From this cruise track, it was found that the accumulated echo integram reflecting the density of pelagir fish biomass was in the range of $0.001-29.225$ tons $/ \mathrm{km}^{2}$ from the total number of 68 points of samples: . Average densities of pelagic fish biomass at the depth range of $<50 \mathrm{~m}$ and $50-100 \mathrm{~m}$ were 1.35 tons and 4.43 tons respertively. The Student-t test applied to the two average densities showed that th" difference between the two layers at $95 \%$ confidence limit was statistirally significant. The schooling behaviour in the morning and afternoon time as reflected by the average density were not significtntly. different. However, from the "Green Index" it was apparent that the schooling biomass tend to orrar in the afternoon. The estimated total biomass of pelagie fish in Lomboh Strait during this period uas about 21.000 tons.

\section{KEYWORDS: pelagic fish, biomass, spatial distribution, Lombok Strait.}

\section{PENDAHULUAN}

Sumber daya ikan pelagis adalah jenis-jenis ikan yang hidup/menghuni perairan lapisan tengah (mid layer) sampai permukaan. Ikan pelagis ini dibagi menjadi dua kelompok besar, yaitu ikan pelagis kecil (layang, kembung, tembang dan lemuru) dan ikan pelagis besar (tuna, cakalang, tongkol, cucut).

Tersedianya data dan informasi tentang potensi dan sebaran (spasial dan temporal) sumber daya ikan di suatu perairan merupakan salah satu dasar bagi langkah-langkah pengembangan pemanfaat. annya. Pola sebaran spasial dan temporal sumber daya ikan di perairan tropis sangat erat kaitannya dengan adanya musim timur, musim barat dan dua musim peralihan yang berlangsung terus-menerus dari tahun ke tahun secara periodik. Musim timur dicirikan oleh berhembusnya angin tenggara ( $S E$ monsoon) dari Australia dan musim barat dicirikan oleh berhembusnya angin barat laut ( $N W$ monsoon) dari Asia (Sugiarto \& Birowo, 1975).

Selat Iombok terletak antara Pulau Bali. Nusia Penida dan Lombok. Bagian utara merupakan bagian dari Laut Bali/Laut Jawa dan bagian selatan yang terbelah dua menjadi Selat Lombok dan Selat Badung merupakan bagian dari Samudera Hindia. Dari kondisi tersebut dapat diduga bahwa secara musiman niassa air Selat Lombok dipengaruhi oleh massa air Samudera Hindia yang bersifat oseanik dengan salinitas tinggi dan massa air Laut Bali/Lalut Jawa dengan salinitas relatif lebih rendah. Salinitis merupakan salah satu parameter yang secara langsung mempengaruhi perilaku pengelompokan ikan, di simping faktor lainnya seperti suhu. poli arus, cahaya dan ketersediaan makanan (Lacvastu \& Larkin. 1981).

Peneliti pada Balai Penelitian Perikaman Laut

Peneliti pada Pusat Penelitian dan Pengembangan Perikanan 
Data dan informasi tentang potensi sumber daya ikan di perairan Selat Lombok masih sangat kurang. Informasi yang ada sebagian besar berupa data statistik perikanan yang meliputi produksi (catch) dan upaya (effort) yang dikeluarkan oleh Dinas Perikanan Daerah. Perairan Selat Lombok merupakan suatu alur penting pelayaran internasional (International sea line) yang menghubungkan Lautan Hindia dan Lautan Pasifik melalui Laut Bali, Selat Makasar dan Laut Sulawesi, yang dilewati kapal-kapal besar terutama kapal-kapal pengangkut minyak dari Timur Tengah ke negara-negara Pasifik Barat terutama Jepang. Kondisi ini menyebabkan perairan ini dihadapkan pada risiko besar terkena pencemaran dan kecelakaan pelayaran (Anonim, 1992), yang pada akhirnya akan mempengaruhi kegiatan usaha penangkapan ikan.

Tulisan ini merupakan hasil penelitian parsial yang dilakukan dalam rangka pengkajian perikanan "kepentingan komersial dan subsistent" di perairan Selat Lombok yang dibiayai oleh Proyek Evaluasi dan Perencanaan Sumber Daya Kelautan (Marine Resource Evaluation and Planning/MREP) bantuan Bank Perkembangan Asia (ADB) bekerja sama dengan Pusat Penelitian dan Pengembangan Perikanan. Hasil penelitian ini diharapkan dapat merupakan informasi tambahan bagi upaya-upaya pemanfaatan sumber daya ikan secara optimal dan berlanjut.

\section{BAHAN DAN METODE}

Pelaksanaan crliise survai dilakukan dengan menggunakan kapal penelitian KM. Sardinella (berkemampuan 64 GT) pada bulan Desember 1997. Luas perairan yang disurvai sepanjang alur track adalah sekitar $3700 \mathrm{~km}^{2}$. Peralatan akustik yang digunakan adalah computerized scientific echosounder SIMRAD EY 500 yang mencatat secara digital. Selama survai berlangsung sepanjang track, alat akustik terus bekerja dan mencatat secara otomatis setiap 30 menit bersamaan dengan pencatatan posisi geografis dengan GPS (Global Positioning System). Hasil pencatatannya dianggap sebagai sampel. Selama survai berlangsung telah dilakukan penarikan contoh (sampel) pada 68 titik, dengan perincian 51 sampel pada waktu antara pukul 06.00-12.00 dan 17 sampel antara pukul 12.30-18.00 (Anonim, 1997a). Data yang diperoleh berupa echogram dengan dua besaran yaitu target strength (TS) dan data echo integram.

Pembagian kisaran kedalaman dilakukan dalam dua lapisan (layers), yaitu lapisan I antara transducer sampai $50 \mathrm{~m}$ dan lapisan II antara 50-100 m. Uji statistik terhadap perbedaan kepadatan biomassa antara kedua lapisan dan antara pagi dan sore hari dilakukan dengan menggunakan Student $t$ - test (Sokal \& Rohlf, 1981).

Perilaku pengelompokan ikan sebagaimana tercermin dari dugaan kepadatan biomassa ikan dihitung dengan "Green Index", GI $=\left(\left(\mathrm{s}^{2} / \mathrm{x}-1\right) /(\mathrm{n}\right.$ 1)), di mana $s^{2}=$ varians, $x$ = nilai rata-rata, dan $n$ = jumlah sampel (Ludwig \& Reynold, 1988).

\section{HASIL DAN BAHASAN}

\section{Selat Lombok}

Secara geografis perairan Selat Lombok terletak pada $115^{\circ} 00^{\prime}-116^{\circ} 00^{\prime}$ BT dan 08 $15^{\prime}$ - 09 $15^{\prime} \mathrm{LS}$. Bagian utara Selat Lombok terbuka lebar sedangkan di bagian selatan terjadi penyempitan oleh adanya pulau Nusa Penida dan Lembongan. Karena posisinya yang relatif sempit yang menghubungkan Perairan Laut Jawa/Laut Bali dan Samudera Hindia kondisi oseanografis Perairan Selat Lombok sangat dinamis. Pengamatan kecepatan arus yang dilakukan dalam rangka kegiatan MREP oleh Tim Pusat Penelitian dan Pengembangan Oseanologi (P3O/LIPI) pada saat yang bersamaan adalah lebih dari $2 \mathrm{~m} /$ detik. Arah arus bervariasi dan sangat dipengaruhi oleh pasang surut. Variasi arah arus tersebut adalah sama sampai dengan kedalaman $100 \mathrm{~m}$. Secara umum arus Perairan Selat Lombok bersifat dua puncak (bi-modal) dengan arah utaraselatan. Pola sirkulasi yang kuat terjadi di Perairan Selat Badung (Anonim, 1997b).

Kegiatan penangkapan ikan oleh nelayan yang sebagian besar bermukim di sekitar Ampenan antara lain meliputi penangkapan ikan pelagis besar dengan tonda, ikan pelagis kecil dengan pukat cincin mini dan jaring bendera (gillnet), serta ikan demersal dengan pancing ladung, bubu dan pukat pantai. Jenis-jenis ikan pelagis kecil didominasi oleh kelompok sardin (Sardinella spp.). Beberapa spesimen dari ikan sardin tersebut dijumpai juga jenis ikan lemuru (Bali oil sardine, Sardinella lemuru) yang berukuran kecil antara $9.11 \mathrm{~cm}$ panjang total.

\section{Kepadatan Biomassa}

Dari hasil analisis data akustik, biomassa ikan pelagis diduga terdiri atas kelompok ikan pelagis kecil dan kelompok ikan pelagis besar. Secara kualitatif ikan pelagis kecil yang tertangkap antara lain adalah Surdinella spp., Rastrelliger spp., dan Selaroides leptolepis (Carangidae). Kelompokikan pelagis besar didominasi oleh jenis-jenis tongkol (Auxis spp., Euthynnus spp.) dan selengseng (Scomber spp.). Dengan tidak tersedianya alat tangkap (purse seine), maka penarikan contoh 
(sampling) penangkapan tidak dilakukan secara memadai sehingga gambaran kuantitatif komposisi jenis ikan pelagis baik ikan pelagis kecil ataupun ikan pelagis besar belum dapat diperoleh. Gambaran biomassa ikan pelagis selama periode survai di Perairan Selat Lombok dapat dilihat pada Tabel 1 . menggerombol ini telah dimanfaatkan dengan baik oleh nelayan, yaitu melalui pemasangan rumpon sebagai alat bantu pengumpul ikan, baik berupa rumpon laut dangkal sebagaimana banyak dijumpai di Laut Jawa, ataupun rumpon laut dalam (payaos) seperti pada perikanan tuna-cakalang. Berbeda dengan kegiatan penangkapan ikan

Tabel 1. Parameter biomassa ikan pelagis di Perairan Selat Lombok.

Table 1. Parameters of pelagic fish biomass in the waters of Lombok Strait.

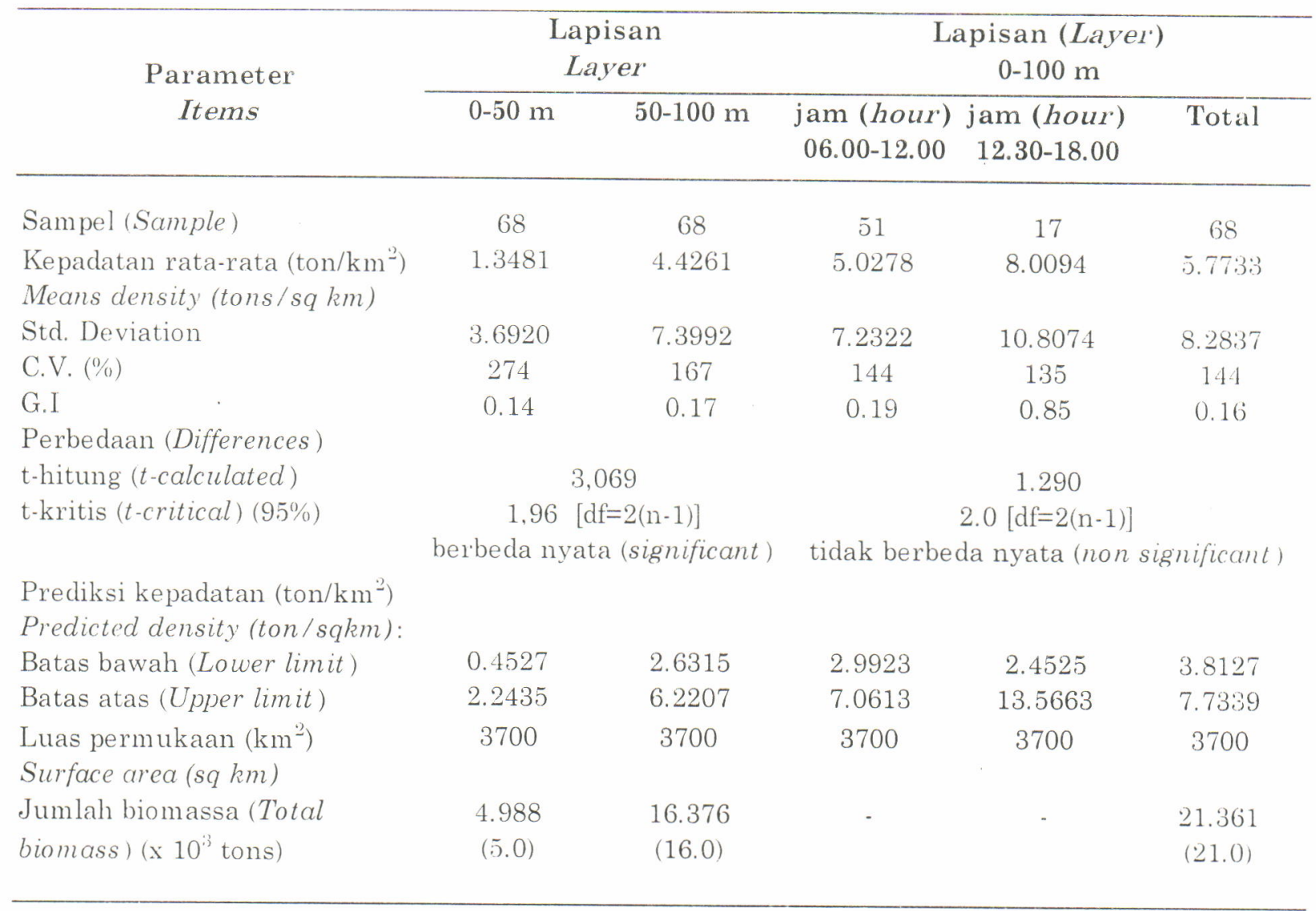

GI = "Green Index"

$\mathrm{CV}=$ koef. variasi (variation coef.)

Selama survai ini telah dilakukan penarikan contoh pada 68 titik dengan kisaran kepadatan antara $0.001-29,225$ ton $/ \mathrm{km}^{2}$ biomassa ikan pelagis. Rata-rata kepadatan biomassa ikan pelagis pada lapisan kedalaman $<50$ m adalah sekitar 1,35 ton/ $/ \mathrm{km}^{2}$ dan antara 50-100 m adalah sekitar 4,43 ton $/ \mathrm{km}^{2}$. Uji statistik dengan Student t-test terhadap dua nilai rata-rata kepadatan biomassa tersebut menunjukkan perbedaan yang nyata (significant) pada selang kepercayaan $95 \%$.

Tingginya hasil penghitungan koefisien variasi (C.V.) dengan nilai masing-masing $274 \%$ dan $167 \%$, menunjukkan bahwa ikan pelagis cenderung untuk menggerombol. Sifat kecenderungan untuk pelagis kecil dengan pukat cincin di Laut Jawa yang menggunakan rumpon dan cahaya lampu, alat bantu pengumpul ikan yang digunakan di Perairan Selat Lombok hanya cahaya lampu. Sebagaimana diketahui bahwa sebagian besar ikan pelagis mempunyai sifat phototaxis positif yaitu tertarik kepada cahaya (Laevastu \& Hayes, 1981).

Dugaan kepadatan biomassa ikan pelagis selama periode survai ini menunjukkan kisaran yang cukup lebar. Kisaran kepadatan biomassa ikan pelagis sebagaimana tercermin dari batas bawah dan batas atas dugaan kepadatan biomassa pada kedalaman sampai 50 m adalah sekitar $0,5-$ 2,6 ton $/ \mathrm{km}^{2}$. Kisaran kepadatan biomassa ikan 
pelagis pada kedalaman antara 50-100 m adalah sekitar 2,2-6,2 ton $/ \mathrm{km}^{2}$ (Tabel 1).

Dugaan biomassa ikan pelagis di Perairan Selat Lombok selama periode survai ini adalah sekitar 21.000 ton. Data terakhir produksi ikan pelagis yang tercatat di Daerah Tingkat II sepanjang Wilayah Timur Bali dan Daerah Tingkat II Lombok Barat adalah sekitar 9000 ton (Anonim, 1997b). Dari data tersebut dapat diduga bahwa tingkat pemanfaatan sumber daya ikan pelagis di perairan Selat Lombok masih relatif rendah. Namun demikian upaya pengembangan pemanfaatan hendaknya dapat diperhitungkan sedemikian rupa mengingat banyaknya faktor-faktor ketidakpastian (uncertainty) yang mempengaruhi kelimpahan biomassa di suatu perairan.

\section{Sebaran Spasial}

Sebaran spasial dan temporal sumber daya ikan di perairan tropis merupakan suatu fenomena umum yang terjadi akibat adanya pengaruh musim. Sebagaimana diketahui bahwa di perairan Laut Jawa terjadi dua musim yang menonjol yaitu musim timur dan musim barat. Pada musim barat oseanografis perairan yang secara langsung pula akan mempengaruhi perilaku penggerombolan ikan di suatu perairan.

Pada waktu survai ini dilakukan, kondisi perairan Selat Lombok sedang berada di bawah pengaruh angin muson barat laut yang tidak terlalu keras. Tampak bahwa kecenderungan pengelompokan biomassa ikan pelagis pada lapisan $\leq 50 \mathrm{~m}$ berada di sekitar perairan Selat Badung (antara Bali-Nusa Penida) sebagaimana dicirikan oleh kelimpahan biomassa yang cukup tinggi (Gambar 1). Perilaku pengelompokan ikan pelagis pada lapisan kedalaman 50-100 m tampak berubah, di mana pemusatan biomassa sebagaimana terlihat pada Gambar 2 terjadi di sekitar perairan Tanjung Sekotong, dan sebagian gerombolan kecil di Lepas Pantai Barat Ampenan dan Barat Laut Nusa Penida ke arah Teluk Padang Bai.

Hasil perhitungan dengan Green Index menunjukkan bahwa perilaku pengelompokan ikan pelagis selama periode survai ini terjadi pada sore hari seperti tercermin dari nilai GI yang tinggi $(\mathrm{GI}=0,85)$. Nilai GI berada pada kisaran 0,0-1,0. Makin tinggi nilai GI, makin tinggi kecenderungan

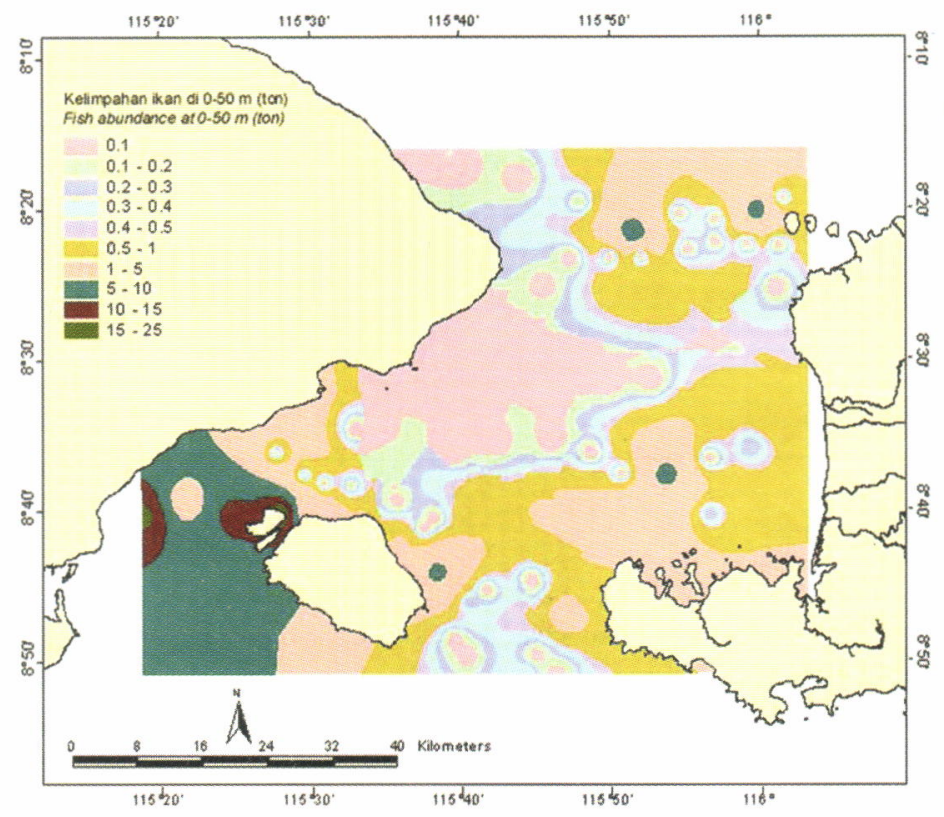

Gambar 1. Sebaran spatial kelimpahan (ton $\left./ \mathrm{km}^{2}\right)$ ikan pelagis pada kedalaman 0-50 $\mathrm{m}$ di Selat Lombok.

Figure 1. Spatial distribution of pelagic fish in layer 0-50 m on Lombok Strait (ton $\left./ \mathrm{km}^{2}\right)$.

berhembus angin muson barat laut sedangkan pada musim timur berhembus angin muson tenggara. Kedua jenis angin musim tersebut berpengaruh langsung terhadap kondisi fisik ikan untuk mengelompok, sedangkan nilai GI = 0,0 mencerminkan sebaran spasial yang acak (Ludwig \& Reynold, 1988). Namun demikian, uji statistik Student $t$-test terhadap dua nilai rata-rata 


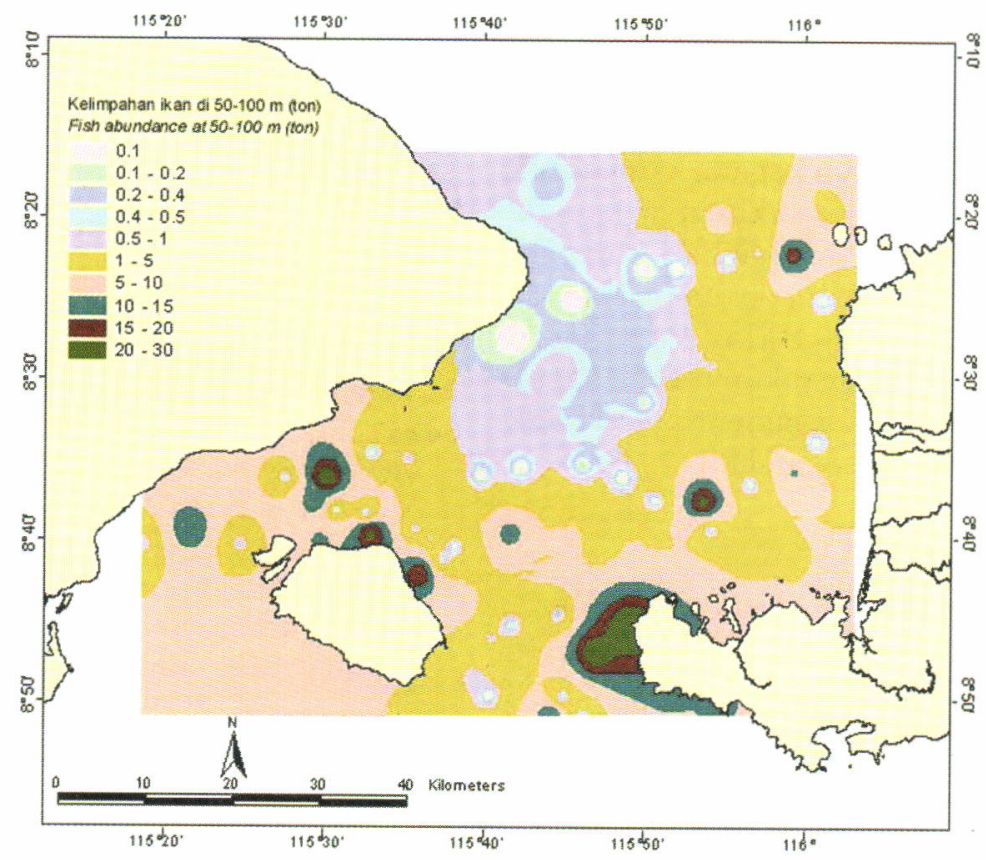

Gambar 2. Sebaran spatial kelimpahan (ton $/ \mathrm{km}^{2}$ ) ikan pelagis pada kedalaman 50-100 m di Selat Lombok.

Figure 2. Spatial distribution of pelagic fish in layer 50-100 m on Lombok Strait (ton $/ \mathrm{km}^{2}$ ).

kepadatan biomassa ikan pelagis pada pagi hari dan sore hari untuk seluruh perairan Selat Lombok tidak menunjukkan perbedaan yang nyata (non significant). Gambaran sebaran spasial biomassa ikan pelagis pada musim timur di mana berhembus angin tenggara yang cukup kuat diduga keras akan mempengaruhi pola sebaran spasial yang berbeda.

\section{KESIMPULAN DAN SARAN}

Dari hasil penelitian dan pembahasan yang telah dikemukakan dapat ditarik beberapa kesimpulan sebagai berikut:

1. Rata-rata kepadatan biomassa ikan pelagis pada lapis kedalaman $<50 \mathrm{~m}$ adalah sekitar $1,35 \mathrm{ton} /$ $\mathrm{km}^{2}$ dan antara 50-100 m adalah sekitar 4,43 ton/ $\mathrm{km}^{2}$. Perbedaan kedua nilai rata-rata kepadatan biomassa tersebut secara statistik pada interval kepercayaan $95 \%$ menunjukkan perbedaan yang nyata (significant).

2. Ikan pelagis di Perairan Selat Lombok secara kualitatif cenderung untuk membentuk gerombolan yang cukup besar, sebagaimana dicirikan oleh tingginya koefisien variasi, yaitu untuk kedalaman sampai $50 \mathrm{~m}$ dan antara 50$100 \mathrm{~m}$ masing-masing $274 \%$ dan $167 \%$.

3. Kecenderungan dari pengelompokan biomassa ikan pelagis secara spasial pada lapis kedalaman $\leq 50 \mathrm{~m}$ berada di sekitar perairan Selat Badung (antara Bali-Nusa Penida), sedangkan untuk lapis kedalaman 50-100 m terjadi di sekitar perairan Tanjung Sekotong dan dua buah pengelompokan kecil terjadi di Lepas Pantai Barat Ampenan dan Barat Laut Nusa Penida ke arah Teluk Padang Bai.

4. Dugaan biomassa ikan pelagis di Perairan Selat Lombok selama periode survai ini adalah sekitar 21.000 ton.

5. Mengingat bahwa data dan informasi yang disajikan merupakan hasil penelitian parsial yang dilakukan pada bulan Desember 1998, yang mendekati puncak periode musim barat di Laut Jawa, informasi yang sama juga diperlukan untuk periode musim timur. Dengan demikian untuk upaya pemanfaatan yang optimal dan berlanjut, masih diperlukan adanya data dan informasi serta pengetahuan yang lebih memadai terutama yang menyangkut sebaran spasial dan temporal biomassa di wilayah tersebut.

\section{UCAPAN TERIMA KASIH}

Dalam kesempatan ini penulis mengucapkan terima kasih kepada Pemimpin Proyek Inven. tarisasi dan Evaluasi Sumber Daya Nasional Matra Laut, BAKOSURTANAL, yang telah memberikan 
bantuan pembiayaan melalui Pusat Penelitian dan Pengembangan Perikanan. Ucapan terima kasih juga kami sampaikan kepada Kepala Pusat Penelitian dan Pengembangan Perikanan yang telah memberikan kepercayaan kepada kami untuk melaksanakan penelitiannya. Akhirnya kepada semua pihak yang telah memberikan bantuan dalam pelaksanaan penelitian ini terutama Nakoda dan ABK Km. Sardinella, Balai Penelitian Perikanan Laut, kami mengucapkan terima kasih. Tanpa bantuan tersebut di atas penelitian ini tidak mungkin dapat dilakukan dengan baik.

\section{DAFTAR PUSTAKA}

Anonim. 1992. Appraisal of the Marine Resource Evaluation and Planning Project (MREP) in Indoncisia. Asican Development Bank. 73 pp.

Anonim. 1997a. Laporan sementara survey sumber daya ikan pelagis di Selat Lombok. MREP.Pusat Penelitian dan Pengembangan Perikanan. 74 hal.
Anonim. 1997b. Pola sirkulasi arus Perairan Selat Lombok. Laporan Survai MREP-P3O LIPI. 60 hal.

Laevastu, T. and Hayes, M.L. 1981. Fisheries Oceanography and Ecology. Fishing News (Books) Ltd. Surrey. England. 199 pp.

Laevastu, T. and Larkin, H.A.. 1981. Marine Fisheries Ecosystems. Fishing News (Books) Ltd. Surrey. England. $162 \mathrm{pp}$.

Ludwig, J.A. and Reynold, J.F. 1988. Statistical Ecology. A primer on methods and computing. John Wiley \& Sons, New York. 337 pp.

Sokal, R.R. and Rohlf, F.J. 1981. Biometry. The principles and practice of statistics in biological research. Freeman and Company. San Fransisco. 859 pp.

Sugiarto, A. dan Birowo, S. 1975 (eds). Atlas Oseanologi Perairan Indonesia dan Sekitarnya. Buku No. 1. Lembaga Oseanologi Nasional/LIPI. Jakarta. 79 hal. 